\title{
Analysis Of Counsel Support With The Time Of Disclosure Of Personal Status Of People with HIV/AIDS (ODHA) Against His Partners In Sumenep District
}

\author{
Dian Permatasari*, Eva Nurhidayati, Dian Ika Puspitasari \\ Wiraraja Madura University, Indonesia \\ *dianpfik@wiraraja.ac.id
}

\begin{abstract}
Human Immunodeficiency Virus and Acquired Immunodeficiency Syndrome (HIV and AIDS) have become epidemics that seriously threaten the health of the world community. The problem of HIV and AIDS is a health challenge in almost all over the world, including in Indonesia. East Java is one of the provinces with the highest number of HIV / AIDS sufferers in Indonesia. As of September 2018, the number of people living with HIV / AIDS was 47,396 people. The data obtained in the field shows that the number of PLWHA in East Java reached 47,396 patients as of September 2018.

This research is a quantitative study with andesign explanatory research that aims to research the effect of the independent and dependent variables through testing.design Cross sectional because the independent and dependent variables were measured at the same time. The sampling technique used total sampling. The instrument in this study was a questionnaire. Data were analyzed using test regression.

One solution to overcome this problem is the role of peer support groups in providing support and services to PLHAs by providing access to information and referrals about treatment. This is important, because both PLHAs and their families need to know how they handle these problems. In addition to providing assistance to PLHAs, peer support groups also provide assistance to community groups who are at high risk of HIV and AIDS transmission. They are, injecting drug users (IDU), female sex workers (FSW), clients of FSW, homosexuals, and people living with HIV / AIDS (OHIDA). Ohida, in this case, is a family living with a person infected with HIV / AIDS.
\end{abstract}

Keywords : HIV / AIDS, ODHA, VCT, KDS

Received August 5, 2020; Revised August 30, 2020; Accepted September 20, 2020 


\section{STRADA Jurnal Ilmiah Kesehatan}

DOI: $10.30994 /$ sjik.v9i2.405

ISSN: 2252-3847 (print); 2614-350X (online)

Vol.9 No.2 November 2020 Page.1128-1133

\section{BACKGROUND}

The problem of HIV and AIDS is a health challenge in almost all over the world, including in Indonesia. Since it was first discovered until June 2018, HIV / AIDS has been reported by 433 (84.2\%) from 514 districts / cities in 34 provinces in Indonesia. The cumulative number of HIV infections reported up to June 2018 was 301,959 people (47\% of the estimated number of people living with HIV AIDS in 2018 were 640,443 people) and most were found in the 25-49 and 20-24 year age group. The provinces with the highest number of HIV infections were DKI Jakarta $(55,099)$, followed by East Java $(43,399)$, West Java $(31,293)$, Papua $(30,699)$, and Central Java $(24,757)$. The number of reported HIV cases continues to increase every year, while the number of AIDS is relatively stable. ARV services can be accessed at hospitals and health centers in 34 provinces, 227 districts / cities. There are currently 896 ARV services in total, consisting of services that can initiate ARV therapy and satellite services. Ministry of Health data for 2017 recorded that of the 48,300 HIV positive cases found, there were 9,280 AIDS cases. Meanwhile, data for the second quarter of 2018 recorded that of 21,336 HIV positive cases, there were 6,162 AIDS cases recorded. The cumulative number of AIDS cases since it was first reported in 1987 to June 2018 was recorded as 108,829 cases.

East Java is one of the provinces with the highest number of HIV / AIDS sufferers in Indonesia. As of September 2018, the number of people living with HIV / AIDS was 47,396 people. Data obtained in the field shows that the number of PLWHA in East Java reached 47,396 patients as of September 2018. The number of people with AIDS was 699 as of June 2018. The majority of PLWHA were men as much as 61.64 percent and women 38.36 percent. Based on age groups, PLWHA are of productive age. In the highest ranking, the age of PLWHA, namely 35-34 years, was 4,050 people, in the second place, 25-29 years old were 3,940 people. Followed by 2,995 PLWHA aged 35-39 years. The findings of new HIV / AIDS cases as of September 2018 were found to be 5,976. The finding of HIV cases has indeed decreased when compared to 2017 of 8,215 cases. However, there is a tendency for sufferers to be reluctant to have themselves checked out because of the fear and stigma of society.

Based on data from the Health Office (Dinkes), the number of HIV / AIDS sufferers as of August 2018 was 69 people. They are scattered in a number of Sumenep Districts. Since 2014 the cases have always increased. This is like an iceberg because the data were checked and found to be positive, "said Kusmawati, Wednesday (19/9/2018). In 2014 there were 24 HIV / AIDS sufferers, 2015 with 40 cases. Meanwhile in 2016 it increased to 24 cases. 50 cases and again jumped to 93 cases in 2017. For 2018 from January to July there were 69 cases and 14 of them died.

They organized themselves, gathered themselves and joined in one organization or peer support group (KDS) organization The role of peer support groups is very significant in providing support and services to PLHAs by providing access to information and referrals about treatment. This is important, because PLHAs and their families need to know how they deal with these problems. assistance to community groups at high risk of HIV infection and AIDS.

\section{METHOD}

This research is a quantitative design with research explanatory research which aims at research conducted to explain the influence between the independent variable and the dependent variable through testing.design Cross sectional because the independent and dependent variables were measured at the same time (Nursalam, 2016). The population in 


\section{STRADA Jurnal Ilmiah Kesehatan}

DOI: $10.30994 /$ sjik.v9i2.405

ISSN: 2252-3847 (print); 2614-350X (online)

Vol.9 No.2 November 2020 Page.1128-1133

this study were 30 PLHAs in the Peer Support Group in Sumenep Regency. The sample in this study were PLHAs who already have partners in peer support groups in Sumenep Regency. The sample size used was a total sample of 20 respondents who met the inclusion criteria, namely: Registered as assisted members of an NGO Peer Support Group (KDS) engaged in HIV AIDS prevention programs in Sumenep District (KDS Sahabat, KDS Arwana and KDS Balada Plus). Residing in the administrative area of Sumenep Regency. Over 15 years of age who already has a partner (boyfriend, husband or wife). Already doing self-disclosure to their partner. Willing to participate as research subjects as evidenced by a signature on the consent sheet or informed consent.

The sampling technique used total sampling. The instrument in this study was a questionnaire. The data were analyzed using test logistic regression.

\section{RESULTS}

Time of disclosure of self-status of PLHAs to partners

\begin{tabular}{|c|c|c|c|}
\hline No & $\begin{array}{c}\text { Time of disclosure of self-status } \\
\text { of PLHAs }\end{array}$ & N & $\%$ \\
\hline 1. & long & 11 & $36.67 \%$ \\
\hline 2. & Fast & 19 & $63.33 \%$ \\
\hline Total & & 30 & $100 \%$ \\
\hline
\end{tabular}

From the table above shows that the time to disclose the self-status of PLHA respondents to partial partners The number of respondents expressed faster, namely 19 people $(63.33 \%)$, while the time to disclose the respondents self-status to the partner in the old category was 11 people $(36.67 \%)$. The time for the disclosure of the respondents selfstatus to his partner in the fastest category was 1 (one) day and the longest was 1,825 days (5 years), while the average time of the respondents disclosure to his partner was 218.46 days.

Counselor Support

\begin{tabular}{|c|c|c|c|}
\hline No & $\begin{array}{c}\text { Data not normally } \\
\text { distributed }\end{array}$ & N & \% \\
\hline $\mathbf{1 .}$ & Support & 20 & $66.67 \%$ \\
\hline $\mathbf{2 .}$ & Not Support & 10 & $33.33 \%$ \\
\hline Total & & 30 & $100 \%$ \\
\hline
\end{tabular}

Cross Tabulation Counselor Support Against Time Disclosure of Self Status in Couples

Coefficients $^{\mathrm{a}}$

\begin{tabular}{|c|c|c|c|c|c|}
\hline Model & $\begin{array}{l}\text { Unstandardized } \\
\text { Coefficients }\end{array}$ & & $\begin{array}{l}\text { Standardized } \\
\text { Coefficients }\end{array}$ & $\mathrm{t}$ & Sig \\
\hline & $\mathrm{B}$ & $\begin{array}{l}\text { Std. } \\
\text { Error }\end{array}$ & Beta & & \\
\hline (Constant) & -.091 & .130 & & $\begin{array}{c}- \\
.705 \\
\end{array}$ & .490 \\
\hline $\begin{array}{l}\text { Conselor } \\
\text { support }\end{array}$ & .258 & .103 & .263 & 2509 & .021 \\
\hline
\end{tabular}

Dependent Variable: Time Disclosure 


\section{STRADA Jurnal Ilmiah Kesehatan}

DOI: $10.30994 /$ sjik.v9i2.405

ISSN: 2252-3847 (print); 2614-350X (online)

Vol.9 No.2 November 2020 Page.1128-1133

Data shown in the table above can be concluded that the respondents who received support from counselors tend to be faster at expressing 20 people $(66.67 \%)$ compared to 10 respondents who did not receive support from counselors (33.33\%). Based on the results of the logistic regression test, it was obtained $\mathrm{p}$-value $=0.021(\mathrm{p}<\alpha$ or $0.000<0.05)$. So statistically it can be interpreted that there is a relationship between counselor support and the time when the respondents self-status discloses to his partner.

\section{DISCUSSION}

Time for Disclosure of Individuals with HIV-AIDS

Disclosure of HIV status is an important part of efforts to prevent HIV transmission and have early access to therapy and care services, prevent recurrent infections and STIs , as well as preventing resistance to treatment The results of this study indicate that the time for disclosing the respondents self-status to the partner, most of the respondents said it was faster, namely 19 people $(63.33 \%)$, while the respondents who took time to reveal their status to their partner were 11 people $(36,67 \%)$. The fastest time to reveal the respondents self-status to his partner is 1 day and the longest is 5 years, while the average time of respondent disclosure to his partner is 218.46 days. Disclosure of HIV status to sexual partners allows partners to make informed choices about reproductive health, which in turn can reduce the number of unwanted pregnancies among HIV positive partners, and even reduce the risk of mother-to-child transmission of HIV. Opening HIV status will be carried out by PLHAs, if there is a guarantee of safety and security when disclosing HIV status. Another possibility that also affects this is the fear of being rejected by the family and no longer respected in their environment. People with HIV tend to tell their loved ones if they feel that the benefits of disclosing their HIV status outweigh the costs. According to Gamavianurs opinion, self-disclosure requires self-confidence to fight the stigma that exists within oneself. Their HIV positive status was self-disclosed based on the level of importance and needs felt by PLHAs.

\section{Analysis of counselor support and the time of disclosure of the status of people with HIV to their partners.}

The counselor is in charge of counseling clients. In doing his job he focuses on client problems and works together with clients to explore options, structure them and implement options. The material contained during the counseling process is the clients trust in the counselor whose confidentiality must be maintained(Dhea et al., 2017)

Based on the results of the logistic regression test, it was obtained p-value $=0.021$ ( $\mathrm{p}<\alpha$ or $0.000<0.05$ ). So statistically it can be interpreted that there is a relationship between counselor support and the time when the respondents self-status discloses to his partner. According to Lowrence Green, the reason someone behaves is because of the influence of people who are very important or significant to us. The important people here are usually parents, grandparents, religious leaders, village leaders, close friends, people where we work, people who have experience and have special skills, people who are willing to help us if needed (in this case an HIV counselor AIDS). From the research results, it can be seen that respondents who received support from counselors tended to reveal their status more quickly to their partners than respondents who did not get support from counselors. Support from counselors tends to be 3 (three) times greater than respondents to express their status more quickly to their partners. The counseling process conducted by counselors tries to encourage respondents to disclose their HIV status to their partners, and the biggest challenge comes from the values in society, most Indonesians are 


\section{STRADA Jurnal Ilmiah Kesehatan}

DOI: $10.30994 /$ sjik.v9i2.405

ISSN: 2252-3847 (print); 2614-350X (online)

Vol.9 No.2 November 2020 Page.1128-1133

not used to discussing sexual / sensitive issues with their partners. (Tirtawati, Kuhu, \& Adam, 2016).

\section{CONCLUSIONS}

Time to disclose the self-status of PLHA respondents to their partners, most of the respondents said it was faster, namely 19 people $(63.33 \%)$. The time for the disclosure of the respondents self-status to his partner with the fastest category is 1 (one) day and the longest is 1,825 days ( 5 years) while the average time of the respondents disclosure to his partner is 218.46 days.

Respondents who received support from counselors tended to be more 20 people $(66.67 \%)$ quickly revealed their status to their partner.

Based on the results of the logistic regression test, it was obtained p-value $=0.021(\mathrm{p}<\alpha$ or $0.000<0.05$ ). So statistically it can be interpreted that there is a relationship between counselor support and the time the respondents self-status discloses to his partner.

\section{ACKNOWLEDGMENTS}

Thank you to the Deputy for Strengthening Research and Development of the Ministry of Research and Technology / the National Research and Innovation Agency of the Republic of Indonesia as a funding source for the Community Partnership Program 2020 according to Decree Number 8 / EI / KPT / 2020.

Thank you to the Rector of Wiraraja University and LPPM of Wiraraja University for facilitating this research activity

The last, Thanks are conveyed to the Health Office of Sumenep Regency, especially for Kalianget, Pamolokan, Batuputih, Saronggi Community Health Center who has been willing to give us permission to carry out this research

\section{REFERENCES}

Dhea, F., Tandi, W., Asrifuddin, A., Sekeon, S. A. S., Kesehatan, F., Universitas, M., \& Ratulangi, S. (2017). HUBUNGAN KETERBUKAAN ODHA PADA PASANGAN DENGAN TINDAKAN PENCEGAHAN PENULARAN HIV / AIDS ( MELALUI SAFER - SEX DAN PMTCT ) PADA KELUARGA DI KOTA MANADO Immunodeficiency Virus ( HIV ) hamil tahun 2016 sebanyak 0 , $49 \%$ dan jumlah ibu hamil positif yang meme, 7 .

Tirtawati, G., Kuhu, F., \& Adam, Y. (2016). Perbedaan Waktu Pengungkapan Status Diri ODHA Terhadap Pasangan Di Manado. Jurnal Ilmiah Bidan, 4(1), 91960.

USAID Indonesia, Taraf Epidemi HIV AIDS Dunia dan Indonesia, tersedia dalam; http://indonesia.usaid.gov/en/home. Jakarta, 2012 diakses tanggal 05-12-19.

Kemenkes RI, Laporan Situasi Perkembangan HIV AIDS di Indonesia Trimester II. Ditjen PP\&PL. Jakarta, 2012.

Irwanto, Pedoman dan Modul Pencegahan Positif. Pusat Penelitian HIV/AIDS Unika Atma Jaya. Jakarta, 2012.

Dinas Kesehatan Kabupaten Sumenep, Laporan situasi perkembangan HIV AIDS di Kabupaten Sumenep, Kabupaten Sumenep, 2018.

Depkes RI, Pedoman Pelayanan Konseling dan Testing HIV/AIDS secara Sukarela (Voluntary Counselling and Testing). Jakarta, 2006.

Murtiastutik, Buku Ajar Infeksi Menular Seksual. Airlangga University Press, Surabaya, 2000. 


\section{STRADA Jurnal Ilmiah Kesehatan}

DOI: $10.30994 /$ sjik.v9i2.405

ISSN: 2252-3847 (print); 2614-350X (online)

Vol.9 No.2 November 2020 Page.1128-1133

Nursalam, Kurniawati D,N, Asuhan Keperawatan Pada Pasien Terinfeksi HIV AIDS, Salemba Medika. Jakarta, 2007.

Yayasan Spiritia, Lembaran Informasi Tentang HIV AIDS Untuk Odha, The Ford Foundation Aksi Stop AIDS \& IHPCP, Jakarta, 2003.

KPAN, Informasi Dasar HIV AIDS. tersedia dalam: http://www.aidsina.org/modules.php?name=FAQ\&myfaq=yes\&id_cat=1\&categories=HIV-AIDS Jakarta, 2012. di akses tanggal 01-12-19.

Departemen Pendidikan Dan Kebudayaan, Kamus Bahasa Indonesia, Volume

1 , Pusat Pembinaan Dan Pengembangan Bahasa Depdikbud, Jakarta, 1983.

KPAN. Stop Stigma Dan Diskriminasi Terhadap Odha. tersedia dalam: http://www.aidsindonesia.or.id.pdf . Jakarta, 2011. di akses tanggal 07-12-19.

Mardhiati Retno, Handayani Sarah, Peran Dukungan Sebaya Terhadap Peningkatan Mutu Hidup Odha Di Indonesia, Yayasan Spiritia, Jakarta, 2011.

Green, Laurence. W. dan Marshall W. Kreuter. Health Promotion Planning And Educational and Environmental Approach. USA: Mayfield Publishing Company : California, 2000 